\title{
Heat-inducible production of $\beta$-glucuronidase in tobacco hairy root cultures
}

\author{
Kung-Ta Lee • Shih-Cheng Chen • Bor-Luen Chiang • \\ Takashi Yamakawa
}

Received: 28 April 2006 /Revised: 7 July 2006 / Accepted: 10 July 2006 / Published online: 7 September 2006

(C) Springer-Verlag 2006

\begin{abstract}
The production of $\beta$-glucuronidase (GUS) driven by the Arabidopsis small heat shock protein 18.2 promoter in liquid cultures of transgenic tobacco (Nicotiana tabacum) hairy roots is reported. Clone GD-3, showing high GUS heat induction and a moderate growth rate, was selected from 436 clones for study. Treatment of GD-3 with heat shock at $36-42^{\circ} \mathrm{C}$ for $2 \mathrm{~h}$ then recovery at $27^{\circ} \mathrm{C}$ resulted in an increase in GUS specific activity, while higher heat-shock temperatures led to a decline. These results were in accordance with the change in esterase activity, a measure of tissue viability. Using $2 \mathrm{~h}$ of $42^{\circ} \mathrm{C}$ heat shock and a recovery phase at $27^{\circ} \mathrm{C}$, GUS specific activity increased rapidly and reached a maximum of
\end{abstract}

\footnotetext{
K.-T. Lee $(\bowtie) \cdot$ S.-C. Chen

Graduate Institute of Microbiology and Biochemistry,

National Taiwan University,

1, Sec. 4, Roosevelt Road,

Taipei, Taiwan, Republic of China

e-mail: ktlee@ntu.edu.tw

Present address:

S.-C. Chen

Division of Pharmacognosy, Section Metabolomics,

Institute of Biology,

University Leiden,

P.O. Box 9502, 2300 RA Leiden, The Netherlands

B.-L. Chiang

Graduate Institute of Clinical Medicine,

National Taiwan University,

1, Sec. 4, Roosevelt Road,

Taipei, Taiwan, Republic of China

T. Yamakawa

Department of Global Agricultural Sciences,

University of Tokyo,

Bunkyo-ku, Tokyo, Japan
}

267.6 nmol 4-methylumbelliferyl $\beta$-D-glucuronic acid (MU) $\min ^{-1} \mathrm{mg}^{-1}$ protein at $24 \mathrm{~h}$ of recovery. When tissues were continuously heated at $42^{\circ} \mathrm{C}$ and tested without a recovery period, GUS mRNA was detectable at $2 \mathrm{~h}$ and peaked at $5 \mathrm{~h}$, but GUS activity was not seen until $10 \mathrm{~h}$ and did not peak until $28 \mathrm{~h}$; in addition, the maximum activity was lower than that seen after heat shock for only $30 \mathrm{~min}$ or $2 \mathrm{~h}$, followed by recovery. This shows that recovery at normal temperature is crucial for the heatinducible heterogeneous expression system of transgenic hairy roots. Multiple heat-shock treatments showed that this system was heat reinducible, although a gradual decline in GUS specific activity was seen in the second and third cycles.

Keywords sHSP18.2 promoter GUS ·

Transgenic hairy roots

\section{Introduction}

For decades, plant cell cultures have been successfully used as chemical factories producing secondary metabolites (Rao and Ravishankar 2002). Commercial protein production has traditionally relied on microbial fermentation and mammalian cell lines. Compared to these traditional expression systems, the use of plant cells results in the folding, assembly, and modification of proteins, as with animal cells, and the cells are inexpensive to grow and maintain, as with microbes (Hellwig et al. 2004). In addition, there is no risk of contamination with oncogenes, prions, mammalian viruses, or mycotoxins or endotoxins from microbes. It has been suggested that they may be useful systems for expressing foreign proteins for commercial applications 
(Su and Aris 2003; Fisher et al. 2004). Although reports of Agrobacterium rhizogenes-mediated transformation for foreign protein production are limited, the hairy roots induced by $A$. rhizogenes are thought to be an ideal system for plant metabolic engineering and an alternative to plant cell suspension cultures for specialty chemical production (Doran 2000). Hairy roots show genetic and biochemical stability, which is lacking in suspension cell cultures, and have a growth rate similar to that of suspension cells (Shanks and Morgan 1999).

The small heat shock protein (sHSP) 18.2 promoter from Arabidopsis thaliana, driving the expression of an $18.2-\mathrm{kD}$ heat shock protein (HSP), was first cloned in 1989 (Takahashi and Komeda 1989). In a previous study (Moriwaki et al. 1999a), the sHSP18.2 promoter was used as a tool to investigate the response to heat shock in transgenic tobacco plants. In gently agitated liquid cultures, the temperature can be controlled more precisely to evaluate the efficiency of the sHSP18.2 promoter in switching on gene expression. In this study, a heatinducible expression model system of tobacco transgenic hairy roots was established for the production of $\beta$-glucuronidase (GUS) and was found to be a useful system for studying the expression of recombinant proteins.

\section{Materials and methods}

The chimeric gene

The binary vector, pHS/GUS, consisting of the Arabidopsis sHSP18.2 promoter, containing heat-shock elements and $77 \mathrm{bp}$ of the sHSP18.2 coding sequence, fused to gus $A$ and which were inserted into pBI101.2, was kindly provided by Prof. Komeda (Takahashi et al. 1992). After confirming the sequences of fused fragments of sHSP18.2 promoter and gus A gene, the plasmid pHS/GUS was transformed into the plasmid carrier host, Escherichia coli strain JM109. Purified binary vector $\mathrm{pHS} / \mathrm{GUS}$ was prepared to transform A. rhizogenes strain 1724 by electroporation; a cuvette with a 1.0-mm-gap chamber for $2.5 \mathrm{kV}$ was used as the conditions. The strain was subsequently screened for kanamycin resistance.

Plant material and liquid cultures of transformed roots

Five-week-old leaf stalks of sterile tobacco explants, Nicotiana tabacum var. TT5 (native fluecurred tobacco var. Taiwan tobacco 5; $\mathrm{P}_{2}$, wide oval leaf), were used to carry out the downstream of $A$. rhizogenes-mediated transformation. Agrobacterium rhizogenes was applied to the cut edges of tobacco leaf discs $\left(\mathrm{ca} .1 \mathrm{~cm}^{2}\right)$ and the leaf discs were placed on a fresh half-strength Murashige and Skoog (MS) agar medium for 4 days at $22^{\circ} \mathrm{C}$ in the dark. Cocultured leaf discs were then transferred to agar media containing $300 \mathrm{mg} \mathrm{L}^{-1}$ cefotaxime to facilitate the sterile cultivation, which lasted 21 days at $27^{\circ} \mathrm{C}$. Induced transgenic hairy roots with a rapid growth rate and without residual A. rhizogenes were established as clones. The rolC and HSP/GUS PCR fragments were sequenced to ensure successful $A$. rhizogenes-mediated transformation.

Liquid cultures of transformed roots were cultivated at $100 \mathrm{rpm}$ at $27^{\circ} \mathrm{C}$ in the dark, and were regularly subcultured every 14 days. One hundred milligrams fresh weight of tissue was used to inoculate a $250-\mathrm{ml}$ flask containing $50 \mathrm{ml}$ of liquid half-strength MS medium supplemented with 3\% sucrose. Growth was measured by weighing the fresh biomass after 21 days of culture (unless otherwise stated) and expressed as the final mass/initial mass.

Heat-shock treatments and GUS specific activity and tissue viability assays

Thirty-day-old (unless otherwise stated) transformed root cultures were subjected to heat shock. Flasks of root cultures were submerged in a water-bath shaker for the indicated period of time at the indicated temperature. Except in the study of the effect of continuous treatment at $42^{\circ} \mathrm{C}$, they were then allowed to recover by culture at $100 \mathrm{rpm}$ at $27^{\circ} \mathrm{C}$ for the indicated time, and then samples were taken to evaluate the heat-induced expression of GUS specific activity and tissue viability.

A total protein extract was prepared by freezing samples in liquid nitrogen and grinding them in a chilled mortar, lyophilizing the tissue, homogenizing it on ice in $0.5 \mathrm{~mL}$ of extraction buffer $\left(50 \mathrm{mM} \mathrm{Na}-\mathrm{PO}_{4}, 10 \mathrm{mM}\right.$ dithiothreitol, $1 \mathrm{mM} \mathrm{Na} 2$ EDTA, $0.1 \%$ Tr0iton X-100, $\mathrm{pH} 7.0$ at $4^{\circ} \mathrm{C}$ ), centrifuging the homogenate at $12,000 \times \mathrm{g}$ for $15 \mathrm{~min}$ at $4^{\circ} \mathrm{C}$, and taking the supernatant. The protein concentration was measured using Bradford's reagent (Biorad) with bovine serum albumin as the standard. This extract was used to measure GUS specific activity by the MU method (Jefferson et al. 1987) (expressed as nmol MU $\mathrm{mg}$ protein $\left.{ }^{-1} \min ^{-1}\right)$. Tissue viability of hairy roots was estimated using fluorescein diacetate (FDA) as substrate to measure cytoplasmic esterase activity (Steward et al. 1999).

DNA extraction, PCR, and probe synthesis

Genomic DNA was extracted from hairy roots using a Plant DNeasy kit (Qiagen, Hilden, Germany). The digoxigenin (DIG)-labeled 401-bp gusA DNA probe was prepared by PCR using pBI101.2 as the template and DIG-labeled 
nucleotides (Roche, Mannheim, Germany). The oligonucleotide primers $5^{\prime}$-ATGTTACGTCCTGTAGAAAC- ${ }^{\prime}$ and 5'-ACACAAACGGTGATACGTAC-3' were used with 35 cycles of $1 \mathrm{~min}$ at $94^{\circ} \mathrm{C}, 1 \mathrm{~min}$ at $55^{\circ} \mathrm{C}$ and $30 \mathrm{~s}$ at $72^{\circ} \mathrm{C}$. The PCR product (401 bp) was analyzed by electrophoresis on a $1 \%$ agarose gel.

RNA extraction and Northern hybridization

Total RNA from hairy roots was isolated using the Trizol ${ }^{\circledR}$ method as described by the manufacturer (Invitrogen, Carlsbad, CA, USA). Ten micrograms of total RNA was separated on a $1.2 \%$ denaturing agarose gel $(50 \mathrm{~V}, 60 \mathrm{~min})$, then the gel was immersed in $20 \times$ saline-sodium citrate (SSC) buffer for $20 \mathrm{~min}$ for equilibrium and blotted onto a nylon membrane $\left(\mathrm{NY}^{+}\right.$membrane, Millipore, Billerica, MA, USA) overnight at room temperature, then crosslinking was performed for $3 \mathrm{~min}$ at $254 \mathrm{~nm}$ using a Biolinker BLX-E254 UV cross linker (Vilber Lourmat, Marne-la-Vallée, France). The membrane was prehybridized in hybridization buffer at $45^{\circ} \mathrm{C}$ for $1 \mathrm{~h}$, then hybridized with the DIG-labeled probe $\left(100 \mathrm{ng} \mathrm{ml}^{-1}\right)$ in the same hybridization buffer for $18 \mathrm{~h}$ at $48^{\circ} \mathrm{C}$, and the membrane was washed with $1 \times \mathrm{SSC}$ containing $0.1 \%$ sodium dodecyl sulfate (SDS) for $10 \mathrm{~min}$ at room temperature, followed by $0.1 \times \mathrm{SSC}$ containing $0.1 \% \mathrm{SDS}$ for $30 \mathrm{~min}$ at $65^{\circ} \mathrm{C}$. The hybridized probe signal was detected using alkaline phosphatase-conjugated anti-DIG antibody (Roche) according to the manufacturer's instructions, and the image was captured using an imaging system (Autochemi, UVP, Upland, CA, USA).

\section{Results}

Establishment of transgenic hairy roots and characterization of clone GD-3

In the establishment of transgenic hairy roots, 436 clones were obtained and 10 completely sterilized clones with high biomass accumulation in flask cultures were finally selected. The rolC and HSP/GUS gene fragments were successfully detected in these 10 clones by PCR (data not shown). For clone selection, the biomasses of these 10 clones and their GUS specific activities at 21 days after heat shock at $40^{\circ} \mathrm{C}$ for $2 \mathrm{~h}$ were compared. Biomass accumulation ranged from 26- to 115-fold and the GUS specific activity ranged from 27.7 to $227.9 \mathrm{nmol} \mathrm{MU} \mathrm{min}^{-1} \mathrm{mg}$ protein $^{-1}$. A tendency was observed for clones with higher accumulated biomass (more than 80 -fold) to express lower heat-inducible GUS activity (data not shown). We finally chose clone GD-3 as the research material, as it showed the highest GUS specific activity and a moderate growth rate.
Growth of GD-3 in a 250-ml flask is shown in Fig. 1. After inoculation with $100 \mathrm{mg}$ of fresh tissues, the transgenic hairy roots grew rapidly from days 14 to 28 , and then entered a stationary phase. The fresh weights of GD-3 on days $14,25,28$, and 30 were $0.3,1.6,2.7$, and $2.9 \mathrm{~g}$, respectively. The relationship between tissue age and heat-inducible GUS specific activity was then investigated. When transgenic hairy roots were cultured for 25,28 , or 30 days, then underwent heat shock at $40^{\circ} \mathrm{C}$ for $2 \mathrm{~h}$ and recovery for $24 \mathrm{~h}$ at $27^{\circ} \mathrm{C}$, the GUS specific activities were 125.3, 198.7, and 278.5 nmol MU $\min ^{-1} \mathrm{mg}$ protein ${ }^{-1}$, respectively, showing that the more mature the tissue, the higher the GUS specific activity induced.

GUS gene expression and specific activity after different heat-shock treatments

The effect of temperatures from 33 to $48^{\circ} \mathrm{C}$ on tissue viability and GUS specific activity was investigated. The intracellular esterase activity in hairy roots was used as a measure of the viability of the tissue. After $2 \mathrm{~h}$ heat shock at $33,36,39$, or $42^{\circ} \mathrm{C}$ and $24 \mathrm{~h}$ at $27^{\circ} \mathrm{C}$ (recovery), GUS specific activity increased with temperature to $21.8,75.3$,

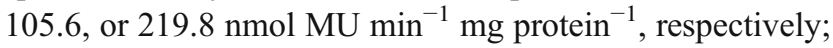
however, at higher temperatures $\left(45\right.$ and $\left.48^{\circ} \mathrm{C}\right)$, it declined (Fig. 2a). In parallel, the tissue viability of transgenic hairy roots subjected to $2 \mathrm{~h}$ of heat shock at 36 or $42^{\circ} \mathrm{C}$ was maintained for at least 5 days in recovery cultures, whereas heat shock at $45^{\circ} \mathrm{C}$ for $2 \mathrm{~h}$ resulted in a rapid increase in esterase activity on day 1 , followed by a dramatic decrease (Fig. 2b).

Heat induction of GUS activity was then investigated in transgenic hairy roots subjected to heat shock at $42^{\circ} \mathrm{C}$ for

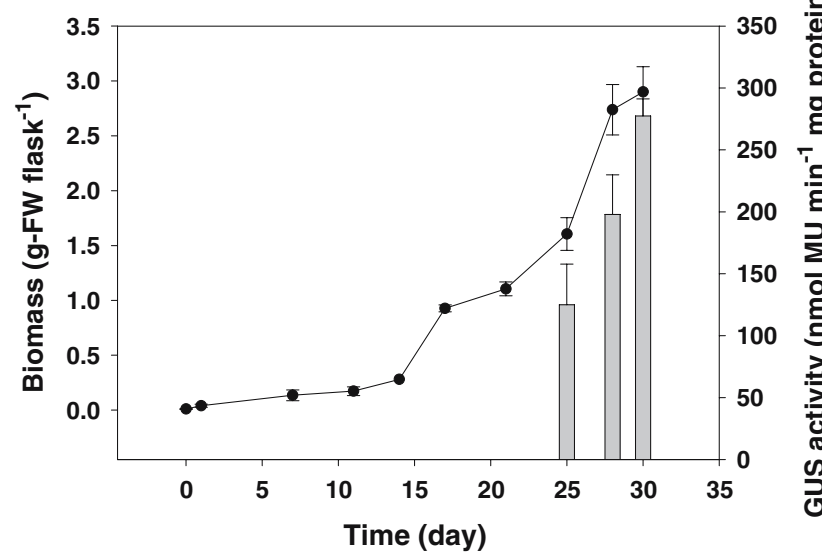

Fig. 1 Growth and GUS specific activity after heat treatment of GD-3 hairy root cultures of different ages. The biomass (black circles) and heat-induced GUS specific activity (gray bars) in 25-, 28-, and 30-day cultures subjected to heat shock at $40^{\circ} \mathrm{C}$ for $2 \mathrm{~h}$ was measured after recovery at $27^{\circ} \mathrm{C}$ for $24 \mathrm{~h}$. The means and standard deviations for triplet experiments are shown 

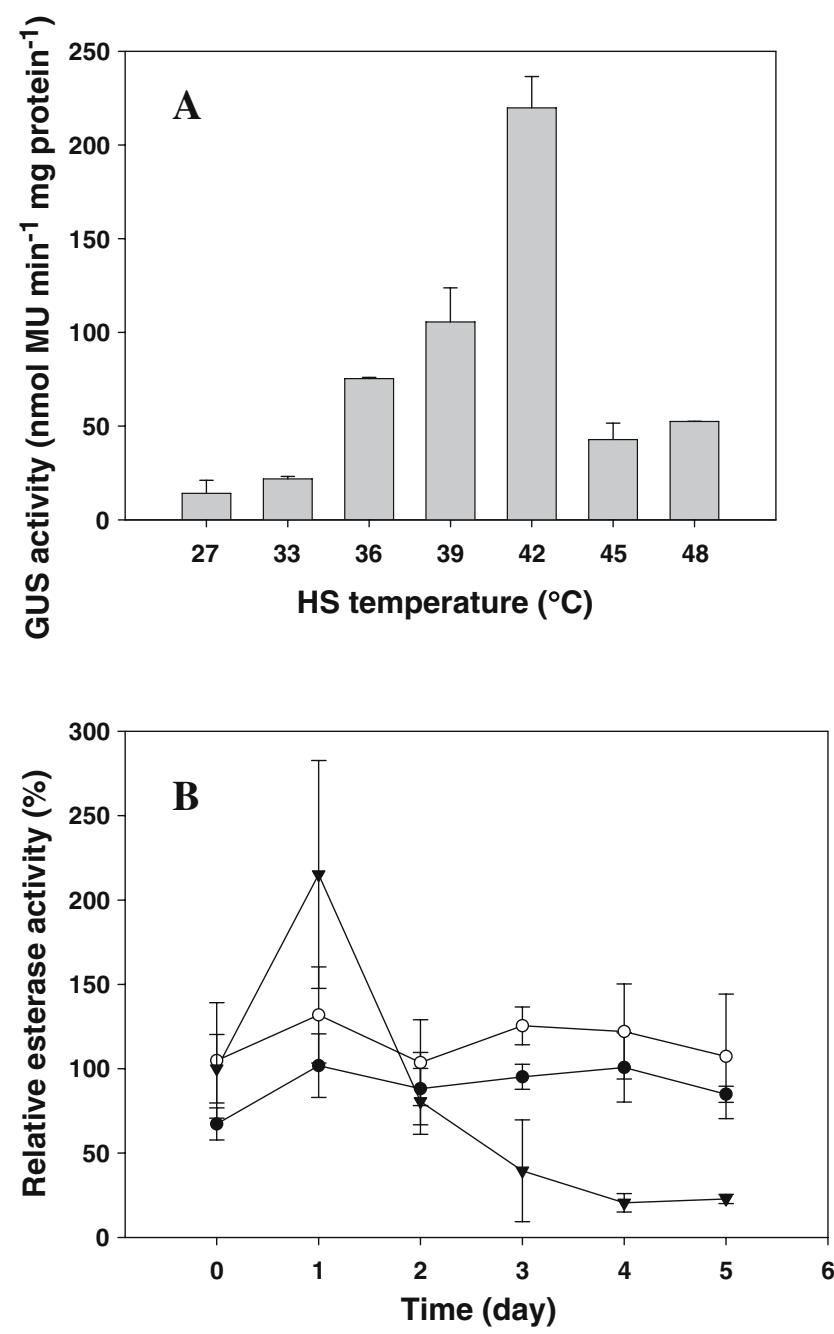

Fig. 2 Effect of temperature on GUS expression and tissue viability of GD-3 transgenic hairy root cultures. a GUS expression; b tissue viability. Thirty-day-old GD-3 root cultures were subjected to different temperatures for $2 \mathrm{~h}$, then allowed to recover at $27^{\circ} \mathrm{C}$ for $24 \mathrm{~h}$ (a) or for $0-5$ days (b). The total protein extracts were assayed for GUS (a) or esterase activity (b), as described in the "Materials and methods." Tissue viability is expressed as a percentage of that of hairy roots with no heat shock. Filled circles, open circles, and triangles represent heat shock at 36,42 , and $45^{\circ} \mathrm{C}$, respectively. The means and standard deviations for triplet experiments are shown

different times. Regarding the heat shock applied for $30 \mathrm{~min}$ and $2 \mathrm{~h}$, transcription of recombinant gus $A$ was observed in the recovery phase at $27^{\circ} \mathrm{C}$, reaching the maximum at 2 and $0 \mathrm{~h}$, respectively, and then decreasing, but remaining detectable at $5 \mathrm{~h}$ (Fig. 3a). As shown in Fig. $3 b$, in the case of heat shock for $2 \mathrm{~h}$, GUS specific activity in transgenic hairy roots during the recovery phase reached a maximum of $267.6 \mathrm{nmol} \mathrm{MU} \mathrm{min}{ }^{-1} \mathrm{mg}_{\text {protein }}{ }^{-1}$ within $24 \mathrm{~h}$, then decreased up to $100 \mathrm{~h}$. Using $30 \mathrm{~min}$ of heat shock, GUS specific activity reached a maximum of $115.5 \mathrm{nmol} \mathrm{MU} \min ^{-1} \mathrm{mg}_{\text {protein }}{ }^{-1}$ after $5 \mathrm{~h}$ of recovery, which was maintained up to $24 \mathrm{~h}$, then gradually decreased.
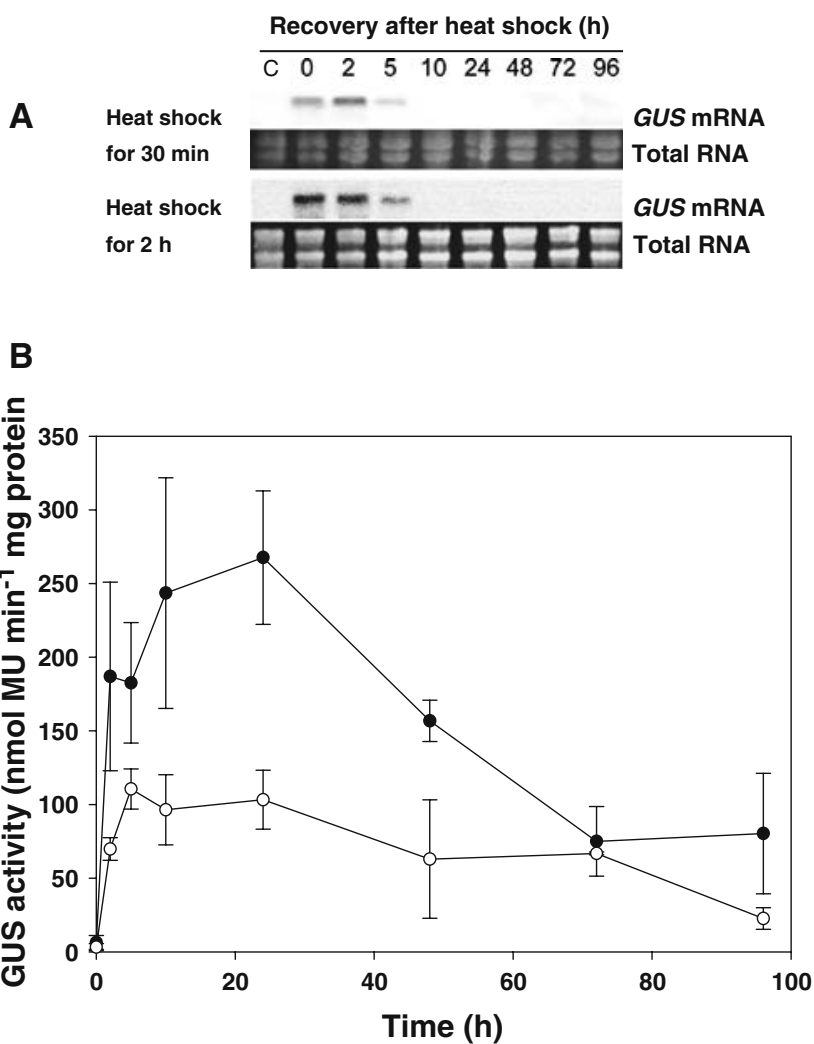

Fig. 3 Time-course of GUS mRNA accumulation and GUS specific activity in transgenic hairy roots subjected to heat-shock at $42^{\circ} \mathrm{C}$ for $30 \mathrm{~min}$ or $2 \mathrm{~h}$, then allowed to recover at $27^{\circ} \mathrm{C}$ for the indicated time. a Northern blots of GUS mRNA. Total RNA was used as the internal control; $C$ is the control (GUS mRNA before heat-shock). b GUS specific activity during the recovery phase at $27^{\circ} \mathrm{C}$ after heat shock for $2 \mathrm{~h}$ (filled circles) or $30 \mathrm{~min}$ (open circles). The means and standard deviations for triplet experiments are shown

In theory (Moriwaki et al. 1999a), HSPs and their mRNAs are produced during the heat-shock period, and their levels decrease following a return to normal temperatures. However, in this study, maximum GUS specific activity was seen during recovery; a similar result of maximum GUS specific activity at $6 \mathrm{~h}$ during the recovery phase was seen when transgenic Arabidopsis plants were exposed to heat shock at $35^{\circ} \mathrm{C}$ for $1 \mathrm{~h}$ (Takahashi et al. 1992).

The effect of continuous heat treatment at $42^{\circ} \mathrm{C}$ with no recovery period on tissue viability, GUS mRNA levels, and GUS specific activity was investigated. As shown in Fig. 4a, transcription was detected within $2 \mathrm{~h}$, reached a maximum at $5 \mathrm{~h}$, then decreased, but was still detectable at 34 h. In contrast, as shown in Fig. 4b, an increase in GUS specific activity was not seen until $10 \mathrm{~h}$ after the start of heat treatment, and the peak GUS specific activity, seen at $28 \mathrm{~h}$, was only $59.4 \mathrm{nmol} \mathrm{MU} \min ^{-1} \mathrm{mg}$ protein ${ }^{-1}$, i.e., only $25 \%$ of the maximum response seen using $2 \mathrm{~h}$ of heat shock at $42^{\circ} \mathrm{C}$ followed by recovery. In accordance with the low GUS specific activity, a decline in tissue viability was seen after $5 \mathrm{~h}$ of heat shock (Fig. 4b). Heat damage of 


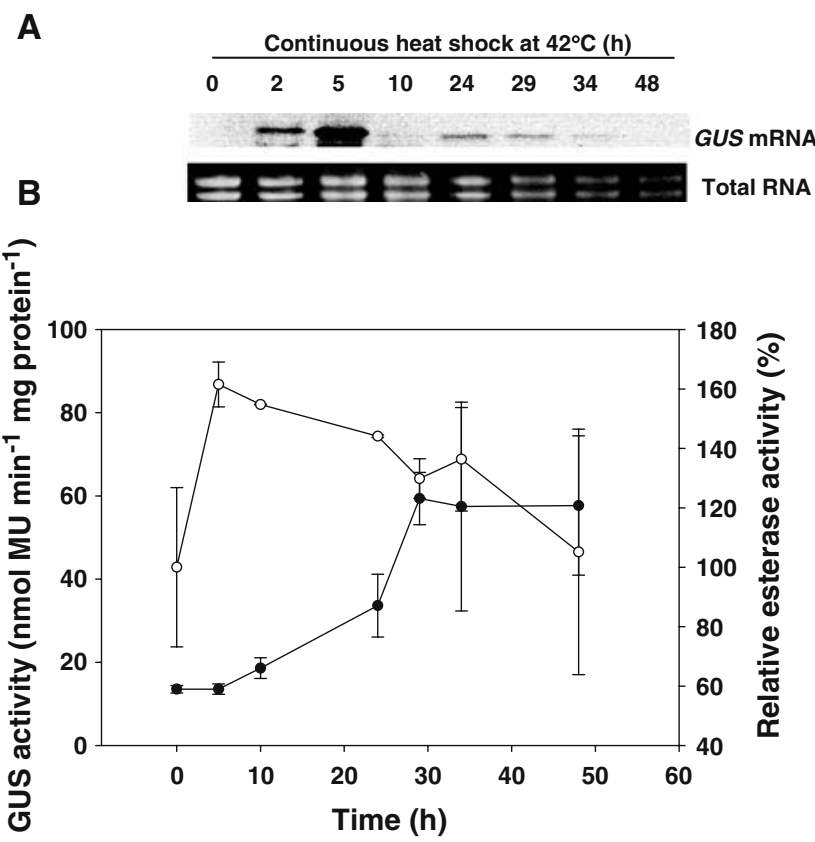

Fig. 4 Time-course of GUS mRNA accumulation and GUS specific activity in transgenic hairy roots subjected to continuous $42^{\circ} \mathrm{C}$ heatshock with no recovery period. a Northern blots of GUS mRNA. Total RNA was used as the internal control. b Heat-induced GUS specific activity (filled circles) and esterase activity (open circles). Tissue viability without heat shock was set as $100 \%$. The means and standard deviations for triplet experiments are shown

the translation system might be responsible for the observed delayed and low GUS specific activity.

Repeated heat shock treatments

The effect of three $2-\mathrm{h} / 42^{\circ} \mathrm{C}$ heat-shock treatments separated by $48 \mathrm{~h}$ of recovery at $27^{\circ} \mathrm{C}$ on induction of GUS activity was investigated. The induced GUS specific activities measured $24 \mathrm{~h}$ after the end of each of the three heat shocks (i.e., at 26,76 , and $126 \mathrm{~h}$ ) were $233.3,212.3$, and $170.3 \mathrm{nmol} \mathrm{MU} \min ^{-1} \mathrm{mg}$ protein ${ }^{-1}$, respectively (Fig. 5). No change in tissue esterase activity was seen following multiple treatments (data not shown). Our results show that, using the optimum heat shock conditions for single treatment $\left(2 \mathrm{~h}\right.$ at $\left.42^{\circ} \mathrm{C}\right)$, heat-induction could be performed several times and without tissue damage, although there was a gradual decline in GUS activity induction in the second and third cycles compared to the first.

\section{Discussion}

For efficient expressions of foreign proteins with high yield, a good expression system using an appropriate promoter is needed. However, overexpression of certain gene products may reduce cell vitality and result in a number of morphological features similar to those seen in

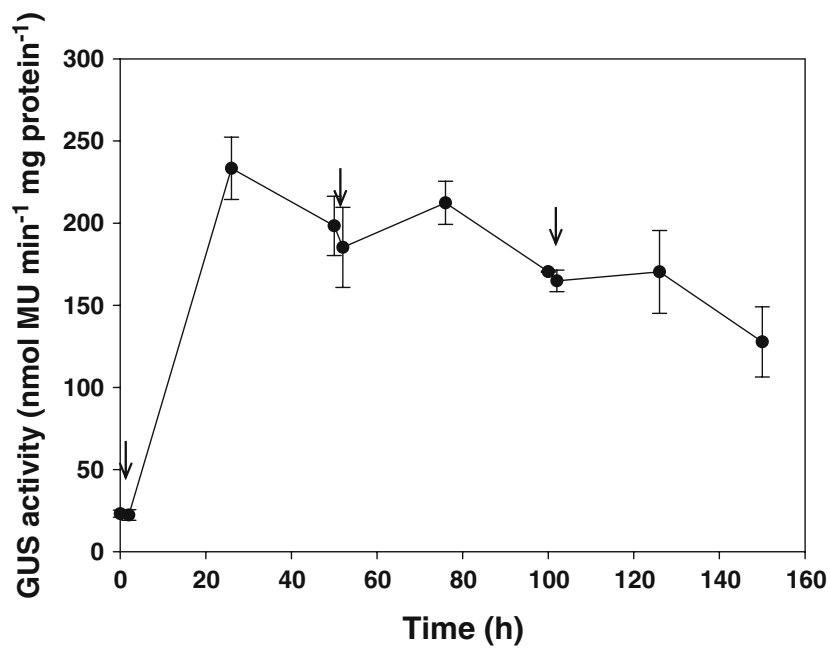

Fig. 5 GUS specific activity in transgenic hairy roots in response to multiple heat shocks. Thirty-day-old GD-3 root cultures were treated for three cycles of $42^{\circ} \mathrm{C}$ for $2 \mathrm{~h}$ and recovery for $48 \mathrm{~h}$ at $27^{\circ} \mathrm{C}$; then, GUS specific activity was measured. The arrows indicate heat shock at $0-2,50-52$, and $100-102 \mathrm{~h}$. The means and standard deviations for triplet experiments are shown

senescent plant tissues. A two-stage culture system consisting of a growth stage and an induction stage is desirable. To date, numerous inducible systems that respond to chemical or physical stimuli have been developed in plant cells, e.g., using wounding (Firek et al. 1993), phytohormones (Li et al. 1991), antioxidants (Herouart et al. 1993), chemicals (Boetti et al. 1999; also see review by Padidam 2003), heat (Yoshida et al. 1995), or light (Shimizu-Sato et al. 2002). However, the use of a chemical, such as salicylic acid, may result in many unexpected physiological manifestations (Shimizu-Sato et al. 2002), and the cost of the inducers, toxicity to the host, or possible induction of unexpected plant physiology-related metabolic pathways should also be concerned. The use of a physical stimulus, such as heat, gives more precise and easy regulation of gene expression.

Cell death in plant cell cultures is usually estimated by coloration methods or specific enzymatic tests (Vaňková et al. 2001). Steward et al. (1999) reported that the in vitro measurement of FDA fluorescence after extraction of the intracellular esterases from Medicago sativa L. (Alfafa) suspension cells could be used to assess cell viability. Using this method, we showed that cytoplasmic esterase activity in transgenic hairy roots decreased at a $45^{\circ} \mathrm{C}$ temperature (Fig. 2b) and caused a low response of the Arabidopsis sHSP18.2 promoter to GUS activity (Fig. 2a). The transient increase in esterase seen at $45^{\circ} \mathrm{C}$ in transgenic hairy roots (Fig. 2b) might also be a response to the heat stress, which then triggered the death mechanism. Our data showed that the FDA method is a simple and efficient way of monitoring tissue viability of transgenic hairy roots in vitro and that, for transgenic tobacco hairy roots, $42^{\circ} \mathrm{C}$ was the optimum temperature for induction of GUS activity without compromising tissue viability. 
A previous study, in which an increase in specific activity was not seen until the recovery period, also showed that a recovery period is crucial to the expression of GUS protein (Takahashi et al. 1992). In contrast to using the $\mathrm{Ha}$ hsp $17.7 \mathrm{G} 4$ promoter with no N-terminal hsp sequence, immediate expression of GUS mRNA and GUS activity were seen in Helianthus annuus (sunflower) when heat shock was applied, using the Ha hsp 17.7 G4 promoter and an N-terminal hsp sequence, a strong induction of gus gene expression but a delayed increase in GUS activity were seen (Almoguera et al. 2002), as in our study (Fig. 3). This difference on onset of the GUS activity increase may be due to the additional N-terminal sequence or to other factors inhibiting GUS activity in vivo, or protein-protein interactions might occur during heat stress. In addition, coaggregation of endogenous and heterologous sHSPs might occur (Kirschner et al. 2000) during the heat shock period.

In $A$. thaliana, the sHSP18.2 promoter shows highest activity at $35^{\circ} \mathrm{C}$, while maximal activity in petunia is seen at $37-38^{\circ} \mathrm{C}$ (Takahashi et al. 1992). However, the optimum temperature for the sHSP18.2 promoter in transgenic Nicotiana plumbaginifolia explants is $42^{\circ} \mathrm{C}$ (Moriwaki et al. 1999a). This shows that the thermosensibility of the sHSP18.2 promoter is species-sensitive. In previous studies, maximal expression activity in transgenic $A$. thaliana was seen $6 \mathrm{~h}$ after a 1 -h heat-shock treatment at $35^{\circ} \mathrm{C}$ (Takahashi et al. 1992), while the maximum in regenerated tobacco explants was seen at $12 \mathrm{~h}$ after a 2 -h treatment at $42{ }^{\circ} \mathrm{C}$ (Moriwaki et al. 1999b) and, in both cases, the GUS specific activity remained high for at least $48 \mathrm{~h}$. However, in this study (Fig. 3), GUS specific activity increased rapidly in $12 \mathrm{~h}$, peaked at $24 \mathrm{~h}$, and then declined. The peak of induced GUS specific activity regulated by the same sHSP18.2 promoter in transgenic $N$. tabacum hairy roots (this study) occurred later than in transgenic N. plumbaginifolia (Moriwaki et al. 1999b) and A. thaliana (Takahashi et al. 1992). However, the maximal level of $267.6 \mathrm{nmol}$ MU $\min ^{-1} \mathrm{mg}$ protein ${ }^{-1}$ induced in our tobacco transgenic hairy root system was 6-fold higher than that in tobacco cells (Yoshida et al. 1995), 18-fold higher than that in tobacco plants (Moriwaki et al. 1999b), and 5-fold higher than that in transgenic Arabidopsis plants (Takahashi et al. 1992). Some possible explanations for the highly expressive activity in A. rhizogenes-transformed $N$. tabacum roots are listed below.

(1) The sHSP18.2 promoter has higher expression efficiency in root tissue. The heat-induced GUS specific activity driven by the sHSP18.2 promoter in tobacco BY-2 cells (Yoshida et al. 1995) was lower than that found in A. rhizogenes-transformed roots (this study). Furthermore, Moriwaki et al. (1999b) detected a higher expression activity of the sHSP18.2 promoter in roots than in other organs in $N$. plumbaginifolia explants. These results suggest that root-differentiated tissues might show better expression. In addition, Sharp and Doran (1999) found that recombinant protein levels were significantly higher in hairy roots than in plant cell suspensions; this higher expression might be due to better recombinant protein expression in $A$. rhizogenes-transformed roots.

(2) The $5^{\prime}$ untranslated region (UTR) of sHSP18.2 may contain sequences that regulate translation efficiency or mRNA stability. In our study, the sHSP18.2 promoter with the $5^{\prime}$ UTR and 77 bp of the sHSP18.2 coding sequence was fused to the $\mathrm{N}$-terminal of gusA, while Dansako et al. (2003) reported that the 5' UTR of the sHSP18.2 gene contributes to efficient translation in plant cells. Thus, $5^{\prime} \mathrm{UTR} / \mathrm{N}$-terminal-mediated translational and/or posttranslational regulation might affect the detected GUS activity.

In this study, a heat-inducible system for exogenous protein expression using tobacco transgenic hairy root was established. This not only provides an alternative way to investigate the physiology of heat shock in plants, but it is also a useful system for target gene expression that is rapid, noninvasive, nontoxic, and easily controlled by heat regulation.

Acknowledgements The authors are very grateful to Prof. Yoshibumi Komeda (Hokkaido University, Japan) for providing the HSP-18.2 gene (PTT119), to Prof. Kouichiro Shimomura (Toyo University, Japan) for providing A. rhizogenes 1724 , and to Dr. TzuHwie Liu (Development Center for Biotechnology, Taiwan) for her kindly provided tobacco seeds. This work was supported by grant NSC92-2313-B-002-116 from the Taiwan National Science Council, Republic of China.

\section{References}

Almoguera C, Rojas A, Jordano J (2002) Reversible heat-induced inactivation of chimeric $\beta$-glucuronidase in transgenic plants. Plant Physiol 129:333-341

Boetti H, Chevalier L, Denmat LA, Thomas D, Thomasset B (1999) Efficiency of physical (light) or chemical (ABA, Tetracycline, $\mathrm{CuSO} 4$ or 2-CBSU)-stimulus-dependent gus gene expression in tobacco cell suspensions. Biotechnol Bioeng 64:1-13

Dansako T, Kato K, Satoh J, Sekine M, Yoshida K, Shinmyo A (2003) $5^{\prime}$ Untranslated region of the HSP18.2 gene contributes to efficient translation in plant cells. J Biosci Bioeng 95:52-58

Doran PM (2000) Foreign protein production in plant tissue cultures. Curr Opin Biotechnol 11:199-204

Firek S, Ozcan S, Warner S, Draper J (1993) A wound-induced promoter during npt-II expression limited to dedifferentiated cells at wound sites is sufficient to allow selection of transgenic shoots. Plant Mol Biol 22:129-142 
Fisher R, Stoger E, Schillberg S, Christou P, Twyman RM (2004) Plant-based production of biopharmaceuticals. Curr Opin Plant Biol 7:152-158

Hellwig S, Drossard J, Twyman RM, Fischer R (2004) Plant cell cultures for the production of recombinant proteins. Nat Biotechnol 22:1415-1422

Herouart D, Van Montagu M, Inze D (1993) Redox-activated expression of the cytosolic copper/zinc superoxide dismutase gene in Nicotiana. Proc Natl Acad Sci USA 90:3108-3112

Jefferson RA, Kavanagh TA, Bevan MW (1987) GUS fusions; $\beta$-glucuronidase as a sensitive and versatile gene marker in higher plants. EMBO J 6:3901-3907

Kirschner M, Winkelhaus S, Thierfelder JM, Nover L (2000) Transient expression and heat-stress-induced co-aggregation of endogenous and heterologous small heat-stress proteins in tobacco protoplasts. Plant J 24:397-411

Li Y, Hagen G, Guilfoyle T (1991) An auxin-responsive promoter is differentially induced by auxin gradients during tropisms. Plant Cell 3:1167-1175

Moriwaki M, Yamakawa T, Washino T, Kodama T, Igarashi Y (1999a) Delayed recovery of $\beta$-glucuronidase activity driven by an Arabidopsis heat shock promoter in heat-stressed transgenic Nicotiana plumbaginifolia. Plant Cell Rep 19:96-100

Moriwaki M, Yamakawa T, Washino T, Kodama T, Igarashi Y (1999b) Organ-specific expression of $\beta$-glucuronidase activity driven by the Arabidopsis heat shock promoter in heat-stressed transgenic Nicotiana plumbaginifolia. Plant Cell Rep 19:92-95

Padidam M (2003) Chemically regulated gene expression in plants. Curr Opin Plant Biol 6:169-177
Rao SR, Ravishankar GA (2002) Plant cell cultures: chemical factories of secondary metabolites. Biotechnol Adv 20:101-153

Shanks JV, Morgan J (1999) Plant 'hairy root' culture. Curr Opin Biotechnol 10:151-155

Sharp JM, Doran PM (1999) Effect of bacitracin on growth and monocloral antibody production by tobacco hairy roots and cell suspensions. Biotechnol Bioeng 4:253-258

Shimizu-Sato S, Huq E, Tepperman JM, Quail PH (2002) A lightswitchable gene promoter system. Nat Biotechnol 20:1041-1044

Steward N, Martin R, Engasser JM, Goergen JL (1999) A new methodology for plant cell viability assessment using intracellular esterase activity. Plant Cell Rep 19:171-176

$\mathrm{Su}$ WW, Aris R (2003) Continuous plant cell perfusion culture: bioreactor characterization and secreted enzyme production. J Biosci Bioeng 95:13-20

Takahashi T, Komeda Y (1989) Characterization of two genes encoding small heat-shock proteins in Arabidopsis thaliana. Mol Gen Genet 219:365-372

Takahashi T, Naito S, Komeda Y (1992) The Arabidopsis HSP18.2 promoter/GUS gene fusion in transgenic Arabidopsis plants: a powerful tool for the isolation of regulatory mutants of the heatshock response. Plant J 2:751-761

Vaňková R, Kuncová G, Opatrná J, Süssenbeková H, Gaudinová A, Vaněk T (2001) Two-dimensional fluorescence spectroscopy-a new tool for the determination of plant cell viability. Plant Cell Rep 20:41-47

Yoshida K, Kasai T, Garcia MRC, Sawada S, Shoji T, Yamazaki S, Komeda Y, Shinmyo A (1995) Heat-inducible expression system for a foreign gene in cultured tobacco cells using the HSP18.2 promoter of Arabidopsis thaliana. Appl Microbiol Biotechnol 44:466-472 